\title{
MEKANISME TRANSMISI SYARIAH PADA SISTEM MONETER GANDA DI INDONESIA
}

\author{
Aam Slamet Rusydiana ${ }^{1}$
}

\begin{abstract}
A bstract
The transmission mechanism of monetary policy has been an area of abundant economic research in many countries. The financial system links monetary policy and the real economy. Thus, events or trends that affect the financial system can also change the monetary transmission mechanism. This study tries to analyze shariah transmission mechanism in Indonesian dual monetary system, using Vector Auto Regression (VAR) and Vector Error Correction Model (VECM) methods.

Results show that the relationship between SWBI (SBI Shariah) and shariah financing (LNFINCG) is negative. It means, when SWBI be higher, the quantity of shariah financing would be lower. And so do $S B I$ and inflation (LNIHK). When the total of shariah financing be increase, it will gives positive contribution for reducing inflation rate in Indonesia, because with this system possibility to make equal growth among monetary and real sectors appears. Therefore, it will be strategic action for monetary authority to grow up shariah banking share in Indonesia, for minimizing 'bad inflation' in economy. Other recommendation, SWBI as shariah monetary instrument should be reconsidered to achieve positive impact for real sector.
\end{abstract}

JEL Classification: C32, E31, E42, E52

Keywords: Shariah Transmission Mechanism, Dual Monetary System, VAR/VECM

1 Staf peneliti pada Lembaga Penelitian dan Pemberdayaan Masyarakat (LPPM) Tazkia Bogor, Indonesia, Email: tasik_pisan@yahoo.com 


\section{PENDAHULUAN}

\section{I.1. Latar Belakang}

Masalah uang adalah masalah yang tidak sederhana. la berkaitan erat dengan hampir seluruh aspek dalam perekonomian. Dan karena alasan ini pula, proses kebijakan moneter sampai menyentuh kepada sektor riil menjadi masalah yang kompleks. Proses ini kemudian lazim disebut sebagai mekanisme transmisi kebijakan moneter. Mekanisme transmisi adalah saluran yang menghubungkan antara kebijakan moneter dengan perekonomian (Pohan, 2008). Bernanke dan Gertler menekankan pada sektor kredit (credit channel) sementara Obstfeld and Rogoff memilih untuk menekankan konsep mekanisme transmisi pada kebijakan nilai tukar (McCallum dalam Hardianto, 2004). Beberapa ekonom sepakat bahwa mekanisme transmisi merupakan proses antara yang menyebabkan perubahan pada GDP riil dan inflasi melalui mekanisme kebijakan moneter.

Otoritas moneter dalam hal ini Bank Indonesia, melalui operasi pasar terbuka menggunakan instrumen tingkat suku bunga SBI untuk mempengaruhi permintaan pinjaman dan pada akhirnya akan mempengaruhi permintaan agregat. Mekanisme transmisi moneter melalui jalur interest rate berawal dari short term rate kemudian menjalar ke medium dan long term rate (Warjiyo, 2003). Saat terjadi kebijakan moneter yang ketat, kenaikan pada tingkat bunga akan membuat penurunan di sektor-sektor yang terkait dengan perbankan akibat kenaikan harga.

Penurunan ini diakibatkan oleh resiko yang diterima peminjam bertambah karena pertambahan biaya bunga sedangkan pendapatan menurun. Pada kondisi dimana terjadi substitusi yang tidak sempurna antara obligasi (bonds) dengan kredit (loan) membuat kedua instrumen mempunyai sifat coexistence, akibatnya perubahan di suku bunga tidak membuat debitur merubah pola investasinya menjadi obligasi. Di lain pihak, kebijakan moneter yang ketat akan membuat peminjam berpindah dari risky loan menuju safe bonds sehingga menurunkan aggregate demand karena investor atau peminjam mengurangi investasinya (Hardianto, 2004).

Sejak tahun 1992, ditandai dengan berdirinya bank syariah pertama yakni Bank Muamalat, di Indonesia terdapat dua sistem perbankan, yaitu sistem bunga (interest rate system) dan sistem bagi hasil atau yang lebih dikenal dengan sistem tanpa bunga (free interest rate system). Semenjak sistem syariah mempunyai instrumen SWBI (Sertifikat Wadiah Bank Indonesia) Indonesia mempunyai dual monetary system yakni mekanisme tingkat bunga dan bagi hasil. Sistem bagi hasil sebagai sebuah prinsip perhitungan berdasarkan pendapatan produsen atau peminjam mempunyai sifat fleksibel terhadap pengembalian bagi hasilnya. 
Dengan sistem ini pertambahan jumlah uang beredar akan mengikuti pertambahan output yang terjadi.

Keberadaan sistem bagi hasil menimbulkan kemungkinan perpindahan konsumen peminjam dari sistem bunga ke bagi hasil. Mekanisme substitusi tersebut membuat terjadinya lack di kebijakan moneter. Kemungkinan lainnya adalah, hal tersebut dapat mereduksi efek negatif pengurangan pinjaman di sektor konvensional. Reduksi ini timbul sebagai akibat dari mekanisme pinjaman syariah yang membuat keseimbangan antara pertumbuhan di sektor moneter dan sektor riil sehingga penambahan proporsi pembiayaan syariah pada perekonomian dapat menekan tingkat inflasi.

\section{I.2. Tujuan}

Studi ini akan mencoba mengidentifikasi proses transmisi moneter syariah di Indonesia melalui salah satu jalur, yakni jalur pembiayaan/financing (dalam konvensional dikenal sebagai jalur kredit). Juga hendak membuktikan apakah mekanisme pembiayaan syariah terutama yang bersifat produktif mampu menyeimbangkan antara pertumbuhan di sektor moneter dan sektor riil sehingga mampu menekan tingkat inflasi. Tujuan lain dari penelitian ini adalah untuk mengukur seberapa efektifkah instrumen-instrumen moneter syariah -berikut juga konvensionalmampu menyentuh sektor riil secara optimal (dalam hal ini variabel pembiayaan perbankan syariah).

\section{I.3. Data dan Metodologi}

Penelitian ini menggunakan metode kuantitatif berupa Vector Autoregression (VAR) yang dilanjutkan dengan Vector Error Correction Model (VECM), apabila terdapat kointegrasi. Sebelumnya, data yang tersedia akan melalui beberapa uji, yakni: uji unit root, uji stabilitas model dan uji kointegrasi. Kurun waktu yang digunakan dalam penelitian ini adalah Juni 2002 sampai dengan Mei 2008. Data yang digunakan berupa data bulanan yang diambil dari berbagai institusi, terutama Bank Indonesia.

\section{TEORI}

\section{II.1. Konsep Mekanisme Transmisi Kebijakan Moneter}

Secara sederhana, mekanisme transmisi kebijakan moneter adalah saluran yang menghubungkan antara kebijakan moneter dan perekonomian. Mekanisme transmisi moneter 
dimulai sejak otoritas moneter atau bank sentral bertindak menggunakan instrumen moneter dalam implementasi kebijakan moneternya hingga terlihat pengaruhnya terhadap aktivitas perekonomian, langsung maupun secara bertahap. Dampak tindakan otoritas moneter terhadap aktivitas perekonomian ini terjadi melalui berbagai channel, yakni: saluran uang atau langsung, saluran suku bunga, kredit, nilai tukar, harga asset dan saluran ekspektasi (Pohan, 2008).

Karena kepelikannya, dalam teori ekonomi moneter, mekanisme transmisi kebijakan moneter kerap disebut dengan "black box" (Mishkin dalam Pohan, 2008). Alasannya adalah karena transmisi moneter ini banyak dipengaruhi oleh tiga factor berikut: (1) perubahan perilaku bank sentral, perbankan dan para pelaku ekonomi dalam berbagai aktivitas ekonomi dan keuangannya; (2) lamanya jeda waktu (time lag) sejak tindakan otoritas moneter hingga sasaran akhir tercapai; dan (3) terjadinya perubahan pada saluran-saluran transmisi moneter itu sendiri sesuai dengan perkembangan ekonomi negara yang bersangkutan.

Dalam suatu perekonomian yang masih tradisional dan sifatnya tertutup dengan perbankan sebagai satu-satunya lembaga keuangan, hubungan antara uang beredar dengan aktivitas ekonomi riil masih relatif erat. Namun, sejalan dengan berkembangnya perekonomian suatu negara dan semakin majunya sektor keuangan, keterkaitan uang beredar dengan sektor riil menjadi semakin renggang. Sebagian dana yang dimobilisasi oleh lembaga keuangan dapat terus berputar di sektor keuangan saja dan tidak menyentuh masyarakat riil. Pola hubungan variabel-variabel ekonomi dan keuangan yang berubah dan semakin tidak erat tersebut akan berpengaruh pada lamanya time lag waktu mekanisme transmisi kebijakan moneter.

Sementara dalam perekonomian yang semakin terbuka sejalan dengan arus globalisasi, perkembangan ekonomi suatu negara akan dipengaruhi pula oleh perkembangan perekonomian di negara lain. Pengaruh ini terjadi melalui perubahan nilai tukar mata uang, kegiatan ekspor impor, serta arus dana masuk dan keluar dari negara yang bersangkutan. Dengan kondisi seperti ini, peranan saluran transmisi seperti suku bunga, kredit dan nilai tukar menjadi semakin penting. Demikian juga peranan saluran harga aset seperti obligasi, saham, dan ekspektasi.

\section{II.2. Tahapan Transmisi Moneter}

Pada dasarnya transmisi kebijakan moneter merupakan interaksi antara bank sentral sebagai otoritas moneter dengan perbankan dan lembaga keuangan lainnya serta pelaku ekonomi lain di sektor riil. Interaksi ini terjadi via dua tahapan proses perputaran uang. Pertama, interaksi antara bank sentral dengan perbankan dan lembaga keuangan lainnya dalam berbagai transaksi di pasar keuangan. Kedua interaksi yang berkaitan dengan fungsi intermediasi antara 
perbankan berikut lembaga keuangan lainnya dengan para pelaku ekonomi dalam berbagai aktivitas di sektor ekonomi riil.

Interaksi tahap pertama di pasar keuangan terjadi pada sistem pengendalian moneter tidak langsung yang sudah lazim dilakukan yakni melalui pasar keuangan. Satu sisi, bank sentral melakukan operasi moneter melalui transaksi keuangan dengan dunia perbankan. Di sisi lain, perbankan melakukan transaksi keuangan dalam portofolio investasinya. Interaksi ini dapat terjadi melalui pasar uang maupun pasar valuta asing. Interaksi antara bank sentral dengan perbankan seperti ini akan berpengaruh terhadap volume maupun harga aset (suku bunga, nilai tukar, yield obligasi dan harga saham).

Interaksi tahap kedua dari transmisi kebijakan moneter melibatkan dunia perbankan dengan para pelaku ekonomi di sektor riil. Dalam konteks ini, perbankan berperan sebagai lembaga intermediasi yakni memobilisasi dana masyarakat dalam bentuk simpanan dan menyalurkannya dalam bentuk kredit dan pembiayaan lainnya kepada masyarakat dan dunia usaha. Di sisi mobilisasi dana, interaksi tersebut akan mempengaruhi suku bunga, volume tabungan dan deposito yang merupakan komponen dari uang beredar M1 (dalam arti sempit) dan M2 (dalam arti luas). Dalam hal perbankan ingin meningkatkan simpanan masyarakat, suku bunga akan dinaikkan sedemikian sehingga minat menabung akan lebih besar. Sementara itu, di sisi penyaluran dana, interaksi tersebut akan berpengaruh pada perkembangan kredit perbankan. Jika perbankan ingin meningkatkan ekspansi kreditnya, suku bunga kredit akan turun sehingga minat untuk meminjam oleh masyarakat meningkat.

\section{II.3. Saluran Transmisi Kebijakan Moneter}

Seperti dikemukakan di awal, sejalan dengan perubahan struktur perekonomian dan perkembangan yang cukup pesat di bidang keuangan, terdapat sedikitnya enam saluran (channels) mekanisme transmisi kebijakan moneter yang sering dikemukakan dalam teori moneter kontemporer. Keenam saluran tersebut meliputi saluran moneter langsung (direct monetary channel), saluran suku bunga (interest rate channel), saluran harga asset (asset price channel), saluran nilai tukar (exchange rate channel), saluran kredit (credit channel) dan saluran ekspektasi (expectation channel).

\section{a. Saluran Langsung (Direct Monetary Channel)}

Transmisi kebijakan moneter saluran langsung atau saluran uang (money channel) mengacu pada teori klasik mengenai peranan uang dalam perekonomian, yang pertama kali dijelaskan oleh Fisher dalam Teori Kuantitas Uang atau Quantity Theory of Money. Pada dasarnya teori ini menggambarkan kerangka yang jelas mengenai analisis hubungan langsung antara 
uang beredar dan harga yang dinyatakan dalam suatu persamaan yang popular: MV = PT. Dalam ekuilibrium, jumlah uang beredar yang digunakan dalam seluruh kegiatan transaksi ekonomi (MV) adalah sama dengan jumlah output nominal yang ditransaksikan dalam ekonomi. Teori kuantitas uang ini menekankan bahwa permintaan uang oleh masyarakat semata-mata adalah untuk keperluan transaksi. Dalam perkembangannya, pendekatan ini diperbaharui oleh Keynes yang menyatakan bahwa motif permintaan masyarakat akan uang adalah untuk keperluan transaksi, berjaga-jaga dan spekulasi.

\section{b. Saluran Suku Bunga (Interest Rate Channel)}

Lain dengan saluran langsung yang menekankan aspek kuantitas proses perputaran uang dalam perekonomian, saluran suku bunga lebih menekankan pentingnya aspek harga di pasar keuangan terhadap berbagai aktivitas ekonomi di sektor riil. Dalam kaitan ini, kebijakan moneter yang ditempuh bank sentral akan berpengaruh terhadap perkembangan berbagai suku bunga di sektor keuangan dan selanjutnya akan berpengaruh pada tingkat inflasi dan output riil. Pada tahap pertama, operasi moneter bank sentral akan mempengaruhi suku bunga jangka pendek seperti suku bunga SBI dan bunga pasar uang antarbank (PUAB). Selanjutnya perubahan ini akan memberikan pengaruh pada suku bunga deposito yang ditawarkan bank ke para penabung dan pada suku bunga kredit yang dibebankan bank kepada para debiturnya. Proses perubahan suku bunga bank ke masyarakat umumnya tidak berlangsung segera, namun ada time lag, terutama karena kondisi internal bank dalam pengelolaan aset dan kewajibannya.

Tahap berikutnya, transmisi suku bunga dari sektor keuangan ke sektor riil akan tergantung pada pengaruhnya terhadap permintaan konsumsi dan investasi. Pengaruh suku bunga terhadap konsumsi berkaitan erat dengan peranan bunga sebagai komponen pendapatan masyarakat dari deposito (income effect) dan bunga kredit sebagai sumber pembiayaan konsumsi (substitution effect). Sementara itu, pengaruh suku bunga terhadap investasi terjadi karena bunga kredit merupakan komponen biaya modal (cost of capital), di samping yield obligasi dan

dividen saham. Pengaruh perubahan suku bunga terhadap investasi dan konsumsi selanjutnya akan berdampak pada permintaan agregat yang pada gilirannya akan menentukan tingkat inflasi dan output riil.

\section{c. Saluran Kredit (Credit Channel)}

Pendekatan mekanisme transmisi kebijakan moneter melalui saluran kredit didasarkan pada asumsi bahwa tidak semua simpanan masyarakat dalam bentuk uang (M1 dan M2) disalurkan oleh perbankan ke masyarakat dalam bentuk kredit. Dengan kata lain, fungsi 
intermediasi perbankan tidak selalu berjalan sempurna, dalam arti bahwa kenaikan simpanan masyarakat tidak selalu diikuti dengan kenaikan secara proporsional kredit yang disalurkan ke masyarakat. Yang lebih berpengaruh terhadap ekonomi riil adalah kredit perbankan, bukan simpanan masyarakat.

Tentang interaksi antara bank sentral, perbankan dan masyarakat riil, pada tahap awal interaksi antara bank sentral dengan perbankan terjadi di pasar uang domestik. Interaksi ini mempengaruhi tidak saja perkembangan suku bunga jangka pendek di pasar uang namun juga besarnya dana yang dialokasikan bank dalam bentuk instrument likuiditas dan dalam pemberian kredit. Tahap selanjutnya transmisi kebijakan moneter dari perbankan ke sektor riil melalui pemberian kredit yang dipengaruhi oleh berbagai faktor, baik internal bank maupun eksternal. Perkembangan kredit perbankan selanjutnya akan berpengaruh pada sektor riil seperti kegiatan konsumsi, investasi dan produksi serta pada gilirannya pada harga-harga barang dan jasa.

\section{d. Saluran Nilai Tukar (Exchange Rate Channel)}

Pendekatan mekanisme transmisi moneter melalui saluran nilai tukar sama seperti saluran suku bunga: menekankan pentingnya aspek perubahan harga aset finansial terhadap berbagai aktivitas perekonomian. Dalam kaitan ini, pentingnya saluran nilai tukar dalam transmisi kebijakan moneter terletak pada pengaruh aset finansial dalam valuta asing yang berasal dari hubungan kegiatan ekonomi suatu negara dengan negara lain. Pengaruhnya bukan saja terjadi pada perubahan nilai tukar tetapi juga pada aliran dana yang masuk dan keluar suatu negara seperti tercermin pada neraca pembayaran. Semakin terbuka ekonomi suatu negara yang disertai dengan sistem nilai tukar mengambang dan devisa bebas, semakin besar pula pengaruh nilai tukar dan aliran dana luar negeri terhadap perekonomian dalam negeri.

Mengenai interaksi antara bank sentral, perbankan dan para pelaku ekonomi dalam proses perputaran uang dapat dijelaskan sebagai berikut. Pada tahap awal, operasi moneter oleh bank sentral akan mempengaruhi, baik secara langsung maupun tidak, terhadap perkembangan nilai tukar. Pengaruh langsung terjadi sehubungan dengan operasi moneter melalui intervensi jual atau beli valuta asing dalam rangka stabilisasi nilai tukar. Sementara pengaruh tidak langsung terjadi karena operasi moneter yang dilakukan oleh bank sentral mempengaruhi perkembangan suku bunga di pasar uang dalam negeri sehingga mempengaruhi perbedaan suku bunga di dalam dan luar negeri (interest rate differential) yang selanjutnya akan berdampak pada besarnya aliran dana dari dan ke luar negeri. Tahap berikutnya, perubahan nilai tukar berpengaruh langsung maupun tidak langsung terhadap perkembangan hargaharga barang di dalam negeri. 


\section{e. Saluran Harga Aset (Asset Price Channel)}

Perubahan harga aset, baik finansial seperti obligasi dan saham maupun fisik seperti properti dan emas, banyak dipengaruhi secara langsung oleh kebijakan moneter. Transmisi ini terjadi karena penanaman dana oleh para investor dalam portofolio investasinya pada umumnya tidak saja berupa simpanan di bank dan instrumen lain di pasar uang, tetapi juga dalam bentuk obligasi, dan saham, serta aset fisik. Perubahan suku bunga dan nilai tukar akan berpengaruh pada volume transaksi dan harga obligasi, saham dan aset fisik tersebut. Selanjutnya, perubahan harga aset dimaksud pada gilirannya akan berdampak pada berbagai aktivitas di sektor riil, seperti permintaan terhadap konsumsi baik karena perubahan kekayaan yang dimiliki (wealth effect) maupun karena perubahan tingkat pendapatan yang dikonsumsi akibat perubahan hasil penanaman aset finansial dan fisik (substitution and income effect).

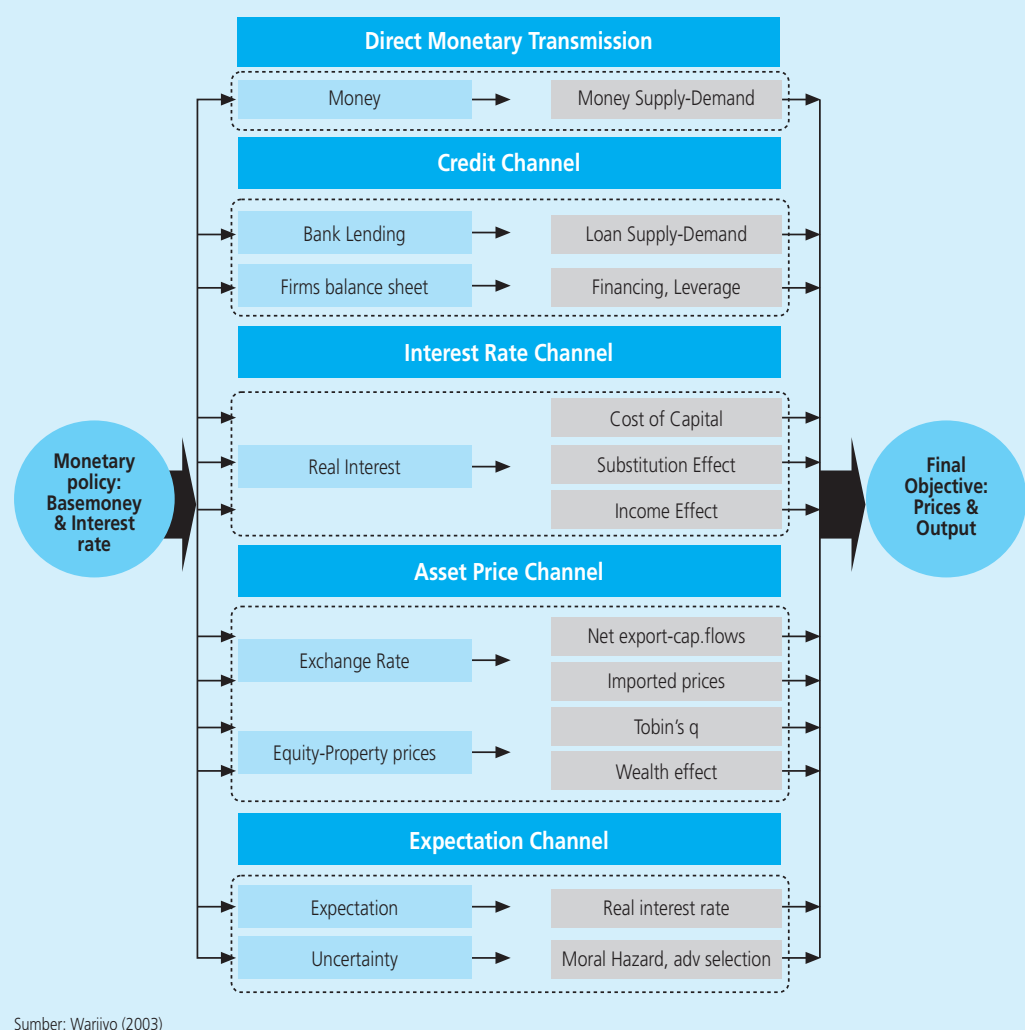

Gambar IV.1

Saluran Transmisi Moneter 
Selain itu, pengaruh harga aset terhadap sektor riil juga terjadi pada permintaan investasi oleh dunia usaha. Ini berkaitan dengan perubahan harga aset tersebut yang memberi dampak terhadap biaya modal yang harus dikeluarkan dalam produksi dan investasi yang gilirannya akan mempengaruhi permintaan agregat, output dan inflasi.

\section{f. Saluran Ekspektasi (Expectation Channel)}

Dalam konteks kebijakan moneter, yang paling diperhatikan adalah ekspektasi inflasi oleh masyarakat. Teori ekspektasi berpendapat bahwa apabila masyarakat cukup rasional, mereka akan mengambil tindakan untuk mengantisipasi kemungkinan terjadinya inflasi. Tindakan tersebut adalah berupa pengurangan jumlah uang yang mereka pegang dengan membelanjakannya ke dalam bentuk barang-barang riil sehingga risiko kerugian memegang uang karena inflasi dapat dihindari. Ekspektasi masyarakat terhadap kenaikan harga pada gilirannya akan mendorong kenaikan tingkat suku bunga. Jika suku bunga meningkat lebih kecil dibandingkan dengan kenaikan harga, secara riil rate of return atas aset finansial menurun dan penurunan tersebut akan mendorong orang mengalihkan kekayaannya dari bentuk aset finansial ke bentuk aset riil.

\section{II.4. Penelitian Terdahulu}

Berikut ini adalah karakteristik penting dari mekanisme transmisi di beberapa negara, baik negara berkembang maupun negara industri maju.

\begin{tabular}{|c|c|}
\hline & $\begin{array}{c}\text { Tabel IV.1 } \\
\text { Mekanisme Transmisi di Beberapa Negara }\end{array}$ \\
\hline Negara & Karakter Penting \\
\hline \multicolumn{2}{|c|}{ Negera Berkembang } \\
\hline Brasil & $\begin{array}{l}\text { Suku bunga mempengaruhi inflasi dengan minimum lag } 6 \text { bulan dan adanya efek } \\
\text { pass-through nilai tukar yang cepat. }\end{array}$ \\
\hline Chili & $\begin{array}{l}\text { Indeksasi mendorong downward price inertia dan telah mempercepat proses transmisi } \\
\text { (sekitar } 3 \text { triwulan) dari shock nilai tukar dan upah ke inflasi. }\end{array}$ \\
\hline Ceska & Mekanisme transmisi diperlemah dengan adanya kerentanan sektor finansial. \\
\hline Israel & $\begin{array}{l}\text { Indeksasi mendorong efek pass-through nilai tukar ke harga yang lebih cepat. } \\
\text { Perkembangan terakhir menunjukkan bahwa dampak tersebut juga lebih panjang. }\end{array}$ \\
\hline Polandia & $\begin{array}{l}\text { Transmisi jalur kredit kurang kuat sebagai akibat dari struktur sektor perbankan dan } \\
\text { pasar keuangan yang kurang berkembang. }\end{array}$ \\
\hline Afrika Selatan & $\begin{array}{l}\text { Suku bunga mempengaruhi inflasi dengan lag, sementara hubungan antara uang } \\
\text { beredar dengan inflasi, lemah. }\end{array}$ \\
\hline
\end{tabular}




\begin{tabular}{|c|c|}
\hline \multicolumn{2}{|r|}{$\begin{array}{c}\text { Tabel IV.1 } \\
\text { Mekanisme Transmisi di Beberapa Negara (lanjutan) }\end{array}$} \\
\hline Negara & Karakter Penting \\
\hline \multicolumn{2}{|l|}{ Negara Industri } \\
\hline Kanada & $\begin{array}{l}\text { Mekanisme transmisi sudah berkembang dengan baik, dengan lag berkisar antara } \\
6-8 \text { triwulan dan bervariasi dari waktu ke waktu. }\end{array}$ \\
\hline Finlandia & $\begin{array}{l}\text { Peralihan ke sistem nilai tukar yang fleksibel telah memperlemah mekanisme transmisi } \\
\text { dan menambah volatilitas nilai tukar. }\end{array}$ \\
\hline Selandia Baru & $\begin{array}{l}\text { Mekanisme transmisi sudah berkembang dengan baik, dengan lag yang berkisar antara } \\
6-8 \text { triwulan dan bervariasi dari waktu ke waktu. }\end{array}$ \\
\hline Spanyol & Nilai tukar riil merupakan jalur transmisi yang paling penting. \\
\hline Swedia & $\begin{array}{l}\text { Mekanisme transmisi sudah berkembang dengan baik, dengan lag berkisar antara } \\
\text { 5-8 triwulan. }\end{array}$ \\
\hline Inggris & $\begin{array}{l}\text { Kebijakan moneter mempunyai efek maksimal terhadap output setelah } 1 \text { tahun dan } \\
\text { terhadap inflasi setelah } 2 \text { tahun. }\end{array}$ \\
\hline
\end{tabular}

Beberapa negara memiliki mekanisme transmisi yang sudah berkembang dengan baik, seperti: Kanada, Selandia Baru, Inggris dan Swedia. Sementara itu, pada umumnya di negara emerging market (negara berkembang) dengan tingkat inflasi yang tinggi, didominasi oleh jalur transmisi dengan karakter downward price stickiness dan efek pass-through yang cepat dari nilai tukar ke inflasi seperti Brasil, Chili dan Israel.

Sementara itu, penelitian yang membahas tentang transmisi moneter syariah, sudah pernah dilakukan oleh Hardianto (2004). Mengambil kasus yang sama di Indonesia, ia menyimpulkan bahwa: (1) Tidak terjadi mekanisme substitusi antara produk pinjaman sistem konvensional dengan sistem syariah, dan (2) Pinjaman bank syariah mempunyai pola hubungan yang positif dengan inflasi IHK. Menurut hasil temuannya, keseimbangan yang seharusnya terjadi antara sisi moneter dengan sisi riil, tidak terjadi karena pertumbuhan pada pinjaman bank syariah tidak diikuti pola yang sama di sisi riil (GDP).

Penelitian yang lain adalah yang dilakukan Nikmawati (2007). Dalam kesimpulannya, ia temukan fakta bahwa sharia financing dapat mengurangi efek negatif suku bunga terhadap inflasi setelah bulan ke-6. Namun di sisi lain, mekanisme substitusi antara sharia financing dengan kredit konvensional, tidak terjadi ketika suku bunga meningkat. Nikmawati menggunakan Malaysia sebagai studi kasusnya. 


\section{DATA DAN METODOLOGI}

\section{III.1. Jenis dan Sumber Data}

Data yang digunakan dalam studi ini adalah data sekunder berupa time series bulanan yang didapat dari Statistika Ekonomi dan Keuangan Indonesia pada Bank Indonesia (SEKI-BI) dan Biro Pusat Statistik (BPS). Seluruh data dimulai dari periode Bulan Juni 2002 hingga Mei 2008. Sebagai variabel dependen, total pinjaman bank syariah adalah jumlah pinjaman yang dikeluarkan oleh perbankan syariah minus BPRS. Tingkat inflasi diproksi menggunakan indeks harga konsumen di Indonesia. Tingkat bunga menggunakan tingkat bunga Pasar Uang Antar Bank (PUAB) untuk all maturities dan Sertifikat Bank Indonesia. Sedangkan tingkat bagi hasil pinjaman secara agregat menggunakan proksi tingkat bagi hasil SWBI dan SBI Syariah serta Pasar Uang Antarbank Syariah (PUAS).

\section{III.2. Metode Estimasi}

Permasalahan dalam studi ini akan dianalisis dengan memakai Vector Autoregression. Secara sederhana, VAR menggambarkan hubungan yang "saling menyebabkan" (kausalistis) antarvariabel dalam sistem, dengan menambahkan intercept. Metode ini mulai dikembangkan oleh Sims pada tahun 1980 (Hasanah, 2007) yang mengasumsikan bahwa semua variabel dalam model bersifat endogen (ditentukan di dalam model) sehingga metode ini disebut sebagai model yang ateoritis (tidak berdasar teori).

Apabila data yang digunakan stasioner pada perbedaan pertama maka model VAR akan dikombinasikan dengan model koreksi kesalahan menjadi Vector Error Correction Model(VECM). Analisis impulse response function dilakukan untuk melihat respon suatu variabel endogen terhadap guncangan variabel lain dalam model. Variance decomposititon analysis juga dilakukan untuk melihat kontribusi relatif suatu variabel dalam menjelaskan variabilitas variabel endogenusnya. Perangkat lunak yang digunakan dalam penelitian ini adalah Microsoft Excel 2003 dan program Eviews 4.1.

Selanjutnya tahapan-tahapan dalam analisis VAR akan dijelaskan seperti pada gambar berikut di bawah ini. 


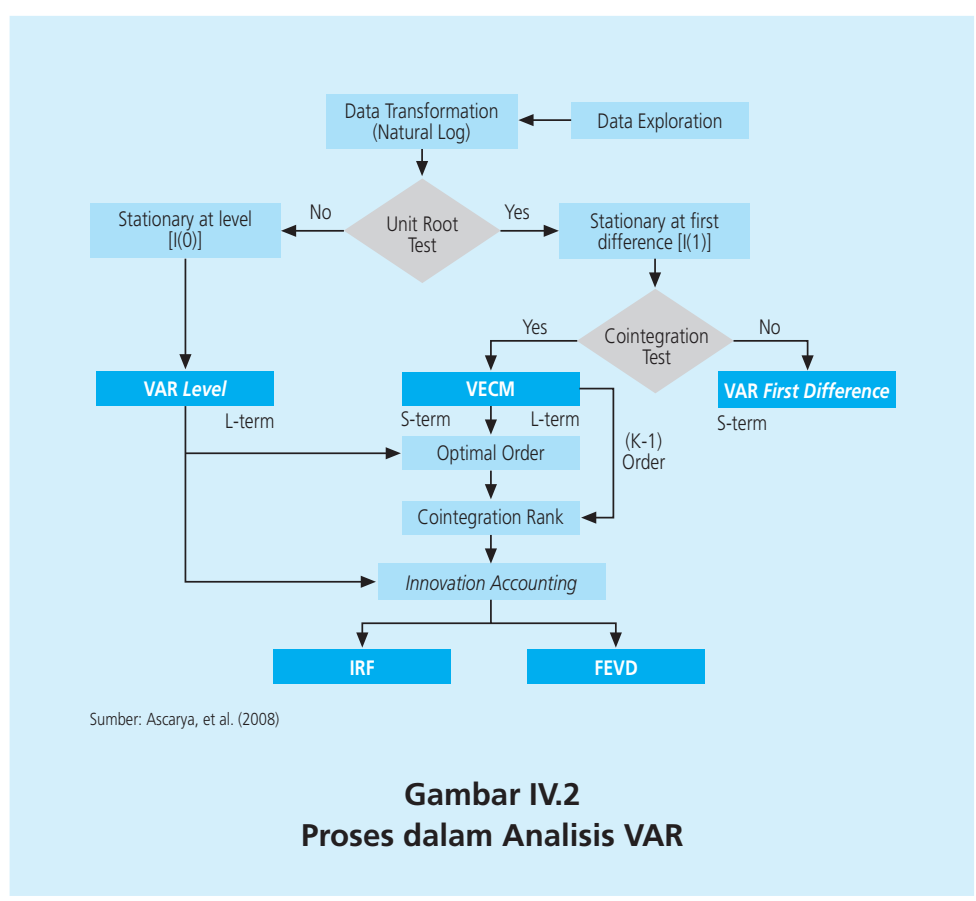

\section{a. Uji Stasioneritas}

Data ekonomi time series umumnya bersifat stokastik atau memiliki tren yang tidak stasioner, artinya data tersebut memiliki akar unit. Untuk dapat mengestimasi suatu model menggunakan data tersebut, langkah pertama yang harus dilakukan adalah pengujian stasioneritas data atau dikenal dengan unit root test. Jika data yang digunakan mengandung unsur akar unit, maka akan sulit untuk mengestimasi suatu model karena tren data tersebut cenderung berfluktuasi tidak di sekitar nilai rata-ratanya. Maka dapat disimpulkan bahwa data yang stasioner akan mempunyai kecenderungan untuk mendekati nilai rata-ratanya dan befluktuasi di sekitar nilai rata-ratanya (Gujarati, 2003).

Lebih khusus, penelitian ini akan menggunakan Augmented Dickey-Fuller (ADF) test dan Phillips-Perron (PP) untuk menguji stasioneritas masing-masing variabel. Hasil dari uji ADF dan PP akan dibandingkan dengan McKinnon Critical Value.

\section{b. Pemilihan Lag Optimum}

Penentuan jumlah lag (ordo) yang akan digunakan dalam model VAR dapat ditentukan berdasarkan kriteria Akaike Information Criterion (AIC), Schwarz Information Criterion (SC) ataupun Hannan Quinnon (HQ). Lag yang akan dipilih dalam model penelitian ini adalah model 
dengan nilai HQ yang paling kecil. Dalam tahapan ini pula dilakukan uji stabilitas model VAR. Penentuan lag optimum dan uji stabilitas VAR dilakukan terlebih dahulu sebelum melalui tahap uji kointegrasi.

\section{c. Uji Kointegrasi}

Jika fenomena stasioneritas berada pada tingkat first difference atau I(1), maka perlu dilakukan pengujian untuk melihat kemungkinan terjadinya kointegrasi. Konsep kointegrasi pada dasarnya untuk melihat keseimbangan jangka panjang di antara variabel-variabel yang diobservasi. Terkadang suatu data yang secara individu tidak stasioner, namun ketika dihubungkan secara linier data tersebut menjadi stasioner. Hal ini yang kemudian disebut bahwa data tersebut terkointegrasi.

Selain itu, uji kointegrasi juga akan dilakukan dengan mengikuti prosedur Johansen. Dalam uji Johansen, penentuan kointegrasi dilihat dari nilai trace statistic dan max eigen statistic setelah didahului dengan mencari panjang lag yang akan diketahui. Nilai trace statistic dan max eigen statistic yang melebihi nilai kritisnya mengindikasikan bahwa terdapat kointegrasi dalam model yang digunakan.

\section{d. Vector Error Correction Model (VECM)}

VECM adalah bentuk Vector Autoregression yang terestriksi. Restriksi tambahan ini harus diberikan karena keberadaan bentuk data yang tidak stasioner namun terkointegrasi. VECM kemudian memanfaatkan informasi restriksi kointegrasi tersebut ke dalam spesifikasinya. Karena itulah VECM sering disebut desain VAR bagi series nonstasioner yang memiliki hubungan kointegrasi.

Setelah diketahui adanya kointegrasi maka proses uji selanjutnya dilakukan dengan menggunakan metode error correction. Jika ada perbedaan derajat integrasi antarvariabel uji, pengujian dilakukan secara bersamaan (jointly) antara persamaan jangka panjang dengan persamaan error correction, setelah diketahui bahwa dalam variabel terjadi kointegrasi. Perbedaan derajat integrasi untuk variabel yang terkointegrasi disebut Lee dan Granger (Hasanah, 2007) sebagai multicointegration. Namun jika tidak ditemui fenomena kointegrasi, maka pengujian dilanjutkan dengan menggunakan variabel first difference.

\section{e. Instrumen Vector Error Correction Model}

Dalam melakukan analisisnya, VAR memiliki instrumen spesifik yang memiliki fungsi spesifik dalam menjelaskan interaksi antarvariabel dalam model. Instrumen itu meliputi Impulse Response 
Function (IRF) dan Forecast Error Variance Decompisitions (FEVD), atau biasa disebut Variance Decompisitions (VD). IRF merupakan aplikasi vector moving average yang bertujuan melihat seberapa lama goncangan dari satu variabel berpengaruh terhadap variabel lain. Sedangkan VD dalam VAR berfungsi untuk menganalisis seberapa besar goncangan dari sebuah variabel mempengaruhi variabel lain.

\section{HASIL DAN ANALISIS}

\section{IV.1. Hasil Uji Stasioneritas Data}

Seperti yang tadi telah disebutkan, metoda pengujian yang digunakan untuk melakukan uji stasioneritas data dalam penelitian ini adalah uji ADF (Augmented Dickey Fuller) dan PhillipsPerron dengan menggunakan taraf nyata lima persen. Jika nilai t-ADF dan t-PP lebih kecil dari nilai kritis MacKinnon, maka dapat disimpulkan bahwa data yang digunakan adalah stasioner (tidak mengandung akar unit).

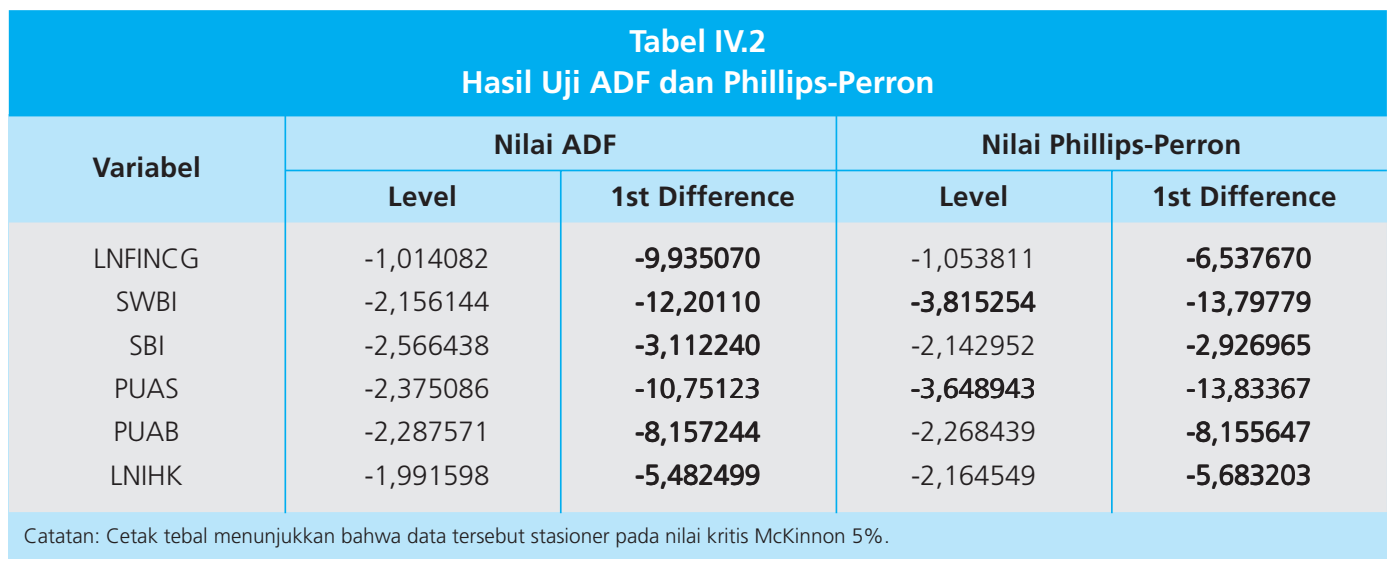

Pengujian akar-akar unit ini dilakukan pada tingkat level sampai dengan first difference. Pada uji ADF, variabel-variabel yang digunakan dalam penelitian ini tidak ada yang mencapai stasioner pada tingkat level. Setelah dilakukan first difference barulah semua data stasioner pada taraf nyata lima persen. Artinya data yang digunakan pada penelitian ini terintegrasi pada ordo satu atau dapat disingkat menjadi I(1). Sementara itu, variabel yang telah stasioner pada tingkat leve/ pada uji Phillips Perron adalah variabel SWBI dan PUAS. Sementara yang lain baru mengalami stasioner pada first difference. Hasil pengujian akar unit dapat dilihat pada tabel IV.2. 


\section{IV.2. Penetapan Lag Optimum}

Pengujian panjang lag optimum ini sangat berguna untuk menghilangkan masalah autokorelasi dalam sistem VAR. Sehingga dengan digunakannya lag optimal diharapkan tidak muncul lagi masalah autokorelasi. Penentuan lag optimal yang digunakan dalam penelitian ini berdasarkan lag terpendek dengan menggunakan Hannan Quinnon (HQ). Hasilnya menunjukkan bahwa model persamaan mengalami lag optimal pada lag 2 (Tabel IV.3).

\begin{tabular}{|c|c|c|c|c|c|c|}
\hline & & & $\begin{array}{l}\text { Tabel } \\
\text { asil Uji Lag }\end{array}$ & timum & & \\
\hline Lag & $\log L$ & LR & FPE & AIC & SC & HQ \\
\hline 0 & 66,47989 & NA & 6,27e-09 & $-1,860920$ & $-1,660207$ & $-1,781726$ \\
\hline 1 & 146,0777 & 142,0516 & $1,65 e-09$ & $-3,202392$ & $-1,797403^{*}$ & $-2,648034$ \\
\hline 2 & 205,3752 & 94,87592 & $8,27 e-10$ & $-3,919237$ & $-1,309972$ & $-2,889714^{\star}$ \\
\hline 3 & 252,9674 & 67,36126 & $6,22 e-10$ & $-4,275920$ & $-0,462379$ & $-2,771233$ \\
\hline 4 & 297,1218 & $54,34390 *$ & $5,60 \mathrm{e}-10$ * & $-4,526825$ & 0,490992 & $-2,546974$ \\
\hline 5 & 329,9368 & 34,32949 & $7,96 \mathrm{e}-10$ & $-4,428823$ & 1,793270 & $-1,973809$ \\
\hline 6 & 385,4783 & 47,85119 & $6,65 e-10$ & $-5,030102 *$ & 2,396267 & $-2,099923$ \\
\hline
\end{tabular}

\section{IV.3. Hasil Uji Stabilitas VAR}

Stabilitas VAR perlu diuji terlebih dahulu sebelum melakukan analisis lebih jauh, karena jika hasil estimasi VAR yang akan dikombinasikan dengan model koreksi kesalahan tidak stabil, maka Impulse Response Function dan Variance Decomposition menjadi tidak valid (Setiawan, 2007). Untuk menguji stabil atau tidaknya estimasi VAR yang telah dibentuk maka dilakukan pengecekan kondisi VAR stability berupa roots of characteristic polynomial. Suatu sistem VAR dikatakan stabil apabila seluruh roots-nya memiliki modulus lebih kecil dari satu (Gujarati, 2003). Berdasarkan uji stabilitas VAR, dapat disimpulkan bahwa estimasi VAR yang akan digunakan untuk analisis IRF dan VD stabil. Ringkasan uji stabilitas VAR dapat dilihat pada tabel IV.4. Dari tabel tersebut dapat diambil kesimpulan bahwa model VAR yang dibentuk sudah stabil pada lag optimalnya.

\begin{tabular}{|c|c|c|c|}
\hline & Hasil Uj & $\begin{array}{l}4 \\
\text { itas VAR }\end{array}$ & \\
\hline Model & Kisaran Modulus & Kisaran Modulus & Kisaran Modulus \\
\hline $\operatorname{Lag} 7$ & $\begin{array}{l}0,969347 \\
0,969347 \\
0,940056\end{array}$ & $\begin{array}{l}0,884954 \\
0,880867 \\
0,880867\end{array}$ & $\begin{array}{l}0,828583 \\
0,828583 \\
0,804156\end{array}$ \\
\hline
\end{tabular}




\begin{tabular}{|c|c|c|c|}
\hline \multicolumn{4}{|c|}{$\begin{array}{c}\text { Tabel IV.4 } \\
\text { Hasil Uji Lag Optimum (Ianjutan) }\end{array}$} \\
\hline Model & Kisaran Modulus & Kisaran Modulus & Kisaran Modulus \\
\hline Lag 7 & $\begin{array}{l}0,940056 \\
0,937806 \\
0,937806 \\
0,923824 \\
0,923824 \\
0,905197 \\
0,905197 \\
0,901538 \\
0,901538 \\
0,892511 \\
0,892511\end{array}$ & $\begin{array}{l}0,879440 \\
0,879440 \\
0,865661 \\
0,865661 \\
0,859634 \\
0,842083 \\
0,842083 \\
0,832658 \\
0,832658 \\
0,828727 \\
0,828727\end{array}$ & $\begin{array}{l}0,645944 \\
0,645944 \\
0,500247 \\
0,500247 \\
0,010429 \\
0,010413 \\
0,010413 \\
0,010377 \\
0,010377 \\
0,010351 \\
0,010351\end{array}$ \\
\hline
\end{tabular}

\section{IV.4. Hasil Uji Kointegrasi}

Pengujian ini dilakukan dalam rangka memperoleh hubungan jangka panjang antarvariabel yang telah memenuhi persyaratan selama proses integrasi yaitu di mana semua variabel telah stasioner pada derajat yang sama yaitu derajat 1, I(1). Informasi jangka panjang diperoleh dengan menentukan terlebih dahulu rank kointegrasi untuk mengetahui berapa sistem persamaan yang dapat menerangkan dari keseluruhan sistem yang ada. Hasil pengujian kointegrasi berdasarkan trace statistics menunjukkan bahwa terdapat dua rank kointegrasi pada taraf nyata lima persen.

\begin{tabular}{c|c|c|c|c}
\multicolumn{5}{c}{$\begin{array}{c}\text { Tabel IV.5 } \\
\text { Hasil Uji Kointegrasi }\end{array}$} \\
$\begin{array}{c}\text { Hypothesized } \\
\text { No. of CE(s) }\end{array}$ & Eigenvalue & $\begin{array}{c}\text { Trace } \\
\text { Statistic }\end{array}$ & $\begin{array}{c}\mathbf{0 . 0 5} \\
\text { Critical Value }\end{array}$ & Prob.** \\
None * & 0,458726 & 118,2077 & $\mathbf{9 5 , 7 5 3 6 6}$ & 0,0006 \\
At most 1 * & 0,395691 & $\mathbf{7 5 , 8 5 3 5 6}$ & $\mathbf{6 9 , 8 1 8 8 9}$ & 0,0152 \\
At most 2 & 0,231223 & 41,10032 & 47,85613 & 0,1855 \\
At most 3 & 0,169807 & 22,95651 & 29,79707 & 0,2482 \\
At most 4 & 0,135173 & 10,11580 & 15,49471 & 0,2719 \\
At most 5 & 0,001379 & 0,095205 & 3,841466 & 0,7577 \\
\end{tabular}

\section{IV.5. Analisis Impulse Response Function}

Setelah melalui serangkaian uji pra-estimasi, yakni uji akar unit, penentuan optimum lag, uji stabilitas VAR hingga uji kointegrasi, dan faktanya terdapat dua rank kointegrasi pada taraf 
nyata lima persen dalam model ini, maka penghitungan dilanjutkan pada tahap selanjutnya yakni VECM. Estimasi VECM dilakukan untuk melihat analisis jangka panjang dan pendek. Berikut ini disajikan simulasi analisis Impulse Response. Rangkuman hasil analisis Impulse Response Function untuk model transmisi syariah melalui jalur pembiayaan ini dapat dibaca pada tabel IV.6. di bawah ini.

\begin{tabular}{|c|c|}
\hline \multicolumn{2}{|c|}{$\begin{array}{c}\text { Tabel IV.6 } \\
\text { Respon Pembiayaan Bank Syariah }\end{array}$} \\
\hline Guncangan Variabel & Respon LNFINCG \\
\hline SWBI & Negatif dan permanen -0.012 , stabil mulai periode ke- 12 \\
\hline $\mathrm{SBI}$ & Negatif dan permanen -0.021 , stabil mulai periode ke-24 \\
\hline PUAS & Negatif dan permanen -0.016 , stabil mulai periode ke-10 \\
\hline PUAB & Positif dan permanen 0.020 , stabil mulai periode ke-10 \\
\hline LNIHK & Negatif dan permanen -0.008 , stabil mulai periode ke- 18 \\
\hline
\end{tabular}

Tabel IV.6. di atas menunjukkan bahwa respon pembiayaan perbankan syariah (LNFINCG) terhadap guncangan variabel lainnya berfluktuasi. Kita dapat mencermati bahwa LNFINCG merespon negatif 1.2 persen terhadap guncangan variabel SWBI sebesar satu standar deviasi. Artinya, semakin tinggi SWBI yang ditetapkan Bank Indonesia, akan semakin rendah jumlah pembiayaan syariah yang diberikan kepada masyarakat. Rasionalisasinya, dengan SWBI/SBI Syariah yang relatif tinggi, perbankan syariah akan cenderung memilih untuk menyimpan dananya di Bank Indonesia dan tidak perlu susah payah melempar dana ke nasabah peminjam. Demikian halnya dengan kondisi Pasar Uang Antarbank Syariah. PUAS direspon negatif sebesar 1.6 persen. Hanya guncangan pada variabel Pasar Uang Antar Bank (PUAB) yang direspon positif oleh pembiayaan perbankan syariah.

Hasil lain dalam analisis IRF yang ditampilkan pada tabel di atas memperlihatkan bahwa, guncangan variabel SBI direspon negatif oleh pembiayaan perbankan syariah sebesar 2.1 persen. Artinya, semakin tinggi SBI akan menyebabkan penurunan pembiayaan syariah, dan sebaliknya. Alasannya, ketika otoritas moneter melakukan kebijakan menaikkan suku bunga SBI, ia akan memicu industri perbankan konvensional untuk menaikkan suku bunganya, baik pinjaman, tabungan maupun suku bunga deposito. Hal ini akan berdampak pada penurunan daya saing perbankan syariah. Return bagi hasil yang diberikan bank syariah akan semakin tidak kompetitif dibanding bunga tabungan dan deposito yang diberikan bank konvensional. Implikasi akhirnya, sangat mungkin perbankan syariah akan 'tidak laku' dan mengalami penurunan dalam hal DPK maupun pembiayaan yang diberikan. 
Sementara guncangan variabel inflasi (LNIHK) direspon negatif oleh LNFINCG sebesar 0.8 persen. Kondisi ini dapat dijelaskan melalui logika berikut. Saat inflasi semakin tinggi, Bank Indonesia sebagai otoritas moneter akan meresponnya dengan menaikkan suku bunga SBI, yang menjadi sebab perbankan konvensional secara umum menaikkan suku bunganya. Seperti kondisi di atas, ketika bunga bank konvensional tinggi akan menyebabkan kurang kompetitifnya perbankan syariah. Pada akhirnya, sangat mungkin jumlah DPK berikut pembiayaan bank syariah akan mengalami penurunan.

\section{Response to Cholesky One S.D. Innovations}
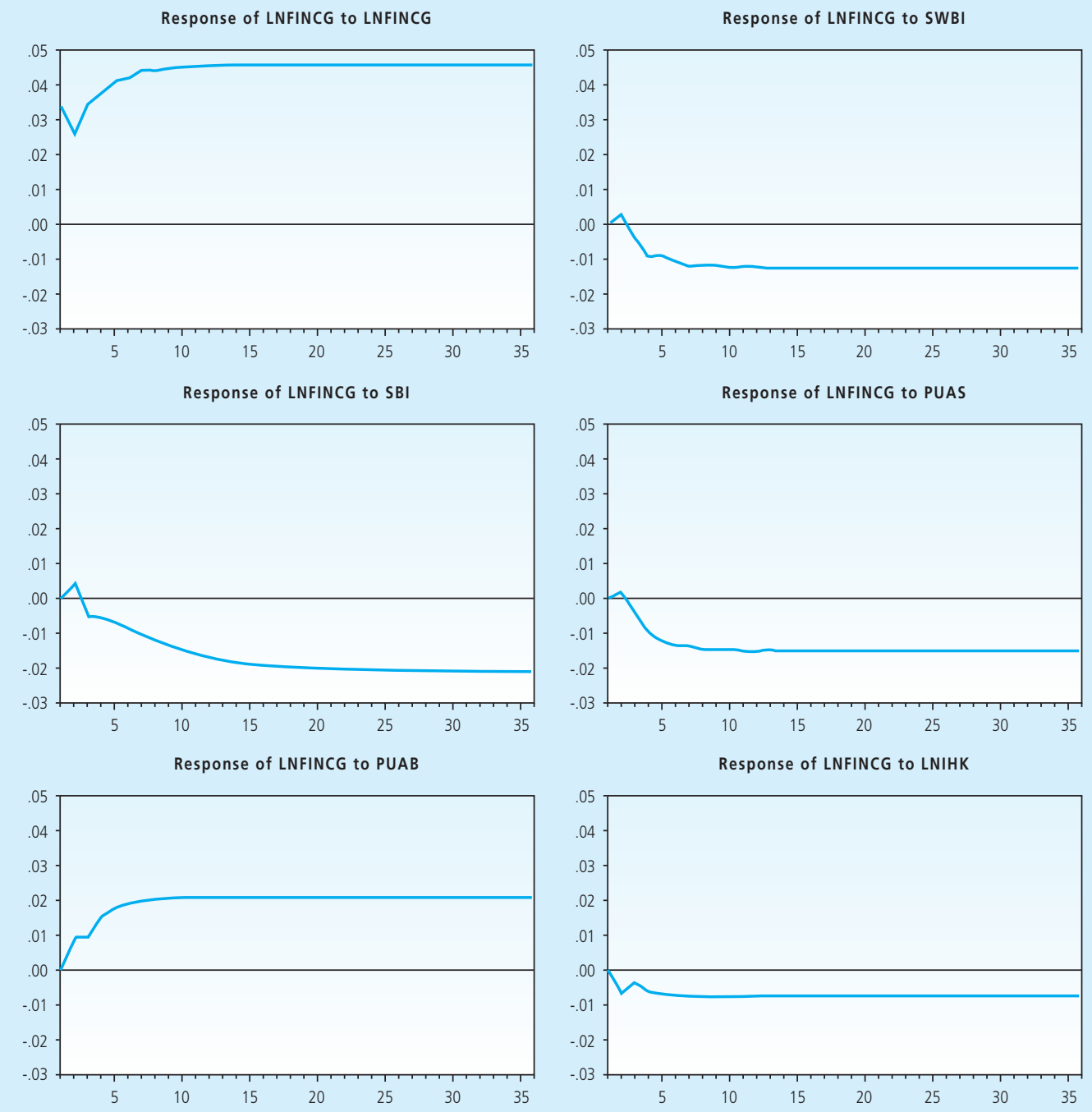

Grafik IV.1

Respon LNFINCG terhadap Beberapa Variabel Instrumen Moneter 
Pembiayaan perbankan syariah (LNFINCG) dapat dikatakan stabil dalam merespon guncangan SWBI setelah periode ke-12 dan mulai stabil dalam merespon guncangan SBI pada periode ke-24. Adapun guncangan variabel Pasar Uang Antar Bank (PUAB) dan Pasar Uang Antarbank Syariah (PUAS) mulai direspon stabil pada periode ke-10. Variabel inflasi direspon negatif oleh LNFINCG dan stabil mulai periode ke-18.

\section{IV.6. Analisis Variance Decomposition}

Setelah menganalisis perilaku dinamis melalui impulse response, selanjutnya akan dilihat karakteristik model melalui variance decomposition. Seperti dapat dilihat pada Grafik IV.2., fluktuasi pembiayaan syariah (LNFINCG) dipengaruhi paling dominan oleh LNFINCG itu sendiri, sedangkan PUAB berada pada urutan kedua mulai dari periode ke-2 hingga periode ke-36, dan SBI pada urutan ketiga. Selanjutnya adalah variabel PUAS dan SWBI. Sedangkan variabel LNIHK tidak terlalu mempengaruhi variabilitas LNFINCG.

Pada periode pertama, fluktuasi variabel pembiayaan syariah (LNFINCG) dipengaruhi oleh guncangan LNFINCG itu sendiri sebesar 100 persen. Pada interval peramalan periode-periode selanjutnya, pengaruh guncangan LNFINCG itu sendiri semakin menurun mempengaruhi variabilitas pembiayaan syariah, tetapi masih sangat dominan. Sedangkan variabel PUAB mulai berperan besar kedua. Pada periode ke-36, variabilitas pembiayaan syariah dapat dijelaskan oleh variabel PUAB dan SBI dengan jumlah kontribusi sebesar 23.1 persen. Sementara pada periode yang sama, variabel PUAS dan SWBI hanya menyumbang sebesar 11.2 persen terhadap variabilitas pembiayaan syariah.

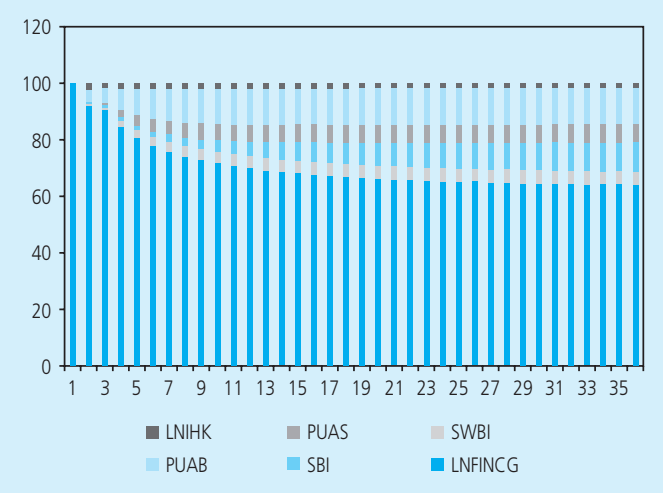

Grafik IV.2

Variance Decomposition Pembiayaan Syariah 
Hasil variance decomposition lainnya, variabel inflasi (LNIHK) berkontribusi kecil terhadap variabilitas LNFINCG, yakni hanya sebesar 1.7 persen. Kontribusi rata-rata inovasi LNFINCG dalam menjelaskan variabilitas pembiayaan syariah dari mulai periode ke-20 sampai periode ke-36 adalah sebesar 64 persen.

\section{KESIMPULAN DAN REKOMENDASI}

\section{V.1. Kesimpulan}

Berdasarkan hasil penelitian yang telah dilakukan mengenai mekanisme transmisi syariah pada sistem moneter ganda di Indonesia, dalam hal ini menggunakan jalur transmisi financing (pembiayaan pada bank syariah), maka diperoleh beberapa kesimpulan, yakni:

- Jika melihat struktur dekomposisi varian, variabel-variabel dalam model yang berkontribusi terhadap pembiayaan perbankan syariah (LNFINCG) berturut-turut adalah: variabel Pasar Uang Antar Bank/PUAB (sebesar 12.7\%), SBI (10.4\%), PUAS (6.6\%), SWBI (4.6\%) dan LNIHK/inflasi (1.7\%). Hasil ini menunjukkan bahwa instrumen moneter konvensional-dalam hal ini PUAB dan SBI- berkontribusi lebih besar (yakni 23.1 persen) terhadap variabel pembiayaan perbankan syariah (LNFINCG) dibanding instrumen syariah sendiri (PUAS dan SWBI yang hanya sebesar 11.2 persen). Hal ini adalah wajar dan dapat dipahami karena saat ini pangsa industri perbankan konvensional jauh lebih besar dibanding perbankan syariah yang hanya sekitar 2\%-share perbankan secara umum.

- Analisis Impulse Response Function (IRF), membuktikan bahwa pola hubungan antara instrumen moneter syariah Sertifikat Wadiah Bank Indonesia (SWBI), yang kemudian berubah menjadi SBI Syariah pada April 2008 tahun lalu, dengan pembiayaan perbankan syariah (LNFINCG) adalah negatif. Artinya, semakin tinggi SWBI yang ditetapkan Bank Indonesia, akan semakin rendah jumlah pembiayaan syariah yang diberikan kepada masyarakat. Ini dapat dipahami karena dengan SWBI/SBI Syariah yang relatif tinggi, perbankan syariah akan cenderung memilih untuk menyimpan dananya di Bank Sentral dan tidak perlu repot untuk melempar dana ke nasabah peminjam. Dampaknya tentu akan menjadi kontraproduktif: masyarakat yang membutuhkan modal akan semakin susah untuk mencari pembiayaan usahanya, termasuk pada perbankan syariah. Demikian pula hubungan yang terjadi antara PUAS dengan LNFINCG.

- Hasil IRF lain memperlihatkan bahwa pola hubungan LNFINCG dengan SBI adalah negatif. Artinya, semakin tinggi SBI akan menyebabkan penurunan pembiayaan syariah, dan sebaliknya. Alasannya, ketika otoritas moneter melakukan kebijakan menaikkan suku bunga SBI, ia akan memicu industri perbankan konvensional untuk menaikkan suku bunganya, baik pinjaman, tabungan maupun suku bunga deposito. Hal ini akan berdampak pada 
penurunan daya saing perbankan syariah. Return bagi hasil yang diberikan bank syariah akan semakin tidak kompetitif dibanding bunga tabungan dan deposito yang diberikan bank konvensional. Langsung ataupun tidak langsung hal ini akan berpengaruh terhadap penurunan jumlah dana pihak ketiga (DPK) yang diterima maupun jumlah pembiayaan (financing) yang disalurkan industri perbankan syariah.

- Kesimpulan lain yang tidak kalah penting adalah bahwa pola hubungan antara LNFINCG dengan LNIHK (inflasi) adalah juga negatif. Kondisi ini dapat dijelaskan melalui logika berikut. Saat inflasi semakin tinggi, Bank Indonesia sebagai otoritas moneter akan meresponnya dengan menaikkan suku bunga SBI, yang menjadi sebab perbankan konvensional secara umum menaikkan suku bunganya. Seperti kondisi di atas, ketika bunga bank konvensional tinggi akan menyebabkan kurang kompetitifnya perbankan syariah. Pada akhirnya, sangat mungkin jumlah DPK berikut pembiayaan bank syariah akan mengalami penurunan.

Namun jika dibaca berkebalikan, maka tesisnya adalah: semakin tinggi jumlah pembiayaan perbankan syariah Indonesia akan berpengaruh dan berkontribusi positif pada penurunan tingkat inflasi Indonesia. Hal ini sekaligus sebagai pembuktian dan 'counter' terhadap hasil riset sejenis yang dilakukan Hardianto pada tahun 2004 silam. Alasan bahwa pembiayaan syariah akan menurunkan tingkat inflasi adalah karena pembiayaan perbankan syariah khususnya pembiayaan produktif berprinsip bagi hasil akan memungkinkan terjadinya pertumbuhan yang seimbang antara sektor moneter dan sektor riil. Keseimbangan tersebut disebabkan oleh prinsip 'profit lost sharing' yang membagi pendapatan (revenue) peminjam.

\section{V.2. Rekomendasi}

Adapun beberapa rekomendasi yang dapat penulis berikan ialah:

- Dengan melihat dampak dari instrumen moneter syariah SWBI atau SBI Syariah yang menyebabkan turunnya pembiayaan perbankan syariah secara umum, kiranya perlu peninjauan ulang terhadap instrumen ini. Alih-alih bank syariah sebagai lembaga intermediasi yang tangguh untuk mendorong aktivitas sektor riil, ia malah berubah menjadi paradigma bank konvensional yang lazim: hanya demi profit setinggi-tingginya dengan abai terhadap debitor yang tunamodal. Jikapun terdapat instrumen moneter sebagai sarana likuiditas bank, diupayakan agar secermat mungkin, tak hanya mirroring dan tentunya 'syariah compliance'.

- Jika pemerintah dan otoritas moneter memiliki kehendak untuk secara serius mengembangkan industri perbankan berbasis bagi hasil di Indonesia, maka salah satu jalan dan upaya untuk mendukung tercapainya kehendak itu adalah dengan mengupayakan agar suku bunga SBI ditekan serendah mungkin. Industri perbankan syariah relatif tidak 
akan 'tumbuh subur dan berkembang' pada negara yang menerapkan bunga tinggi dalam perekonomiannya.

- Salah satu kesimpulan dalam penelitian ini mengatakan bahwa, dengan semakin tinggi jumlah pembiayaan perbankan syariah Indonesia maka akan berpengaruh positif pada penurunan tingkat inflasi Indonesia. Oleh karenanya, merupakan pemikiran yang strategis bagi para pemegang otoritas untuk mengembangkan share industri perbankan syariah di Indonesia, dalam rangka mengatur dan mengendalikan inflasi serta aneka dampak buruknya hingga titik yang paling minimal.

- Yang perlu kita cermati, jenis pembiayaan syariah yang terindikasi mampu menurunkan tingkat inflasi dan memungkinkan terjadinya pertumbuhan yang seimbang antara sektor moneter dan sektor riil adalah skema jenis pembiayaan produktif dan partnership seperti: mudharabah atau musyarakah. Sehingga, memperbanyak akad transaksi berbentuk 'profit loss sharing' tersebut perlu menjadi prioritas utama perbankan syariah manapun di Indonesia.

- Terdapat kekurangan dalam riset ini, diantaranya adalah: variabel pembiayaan perbankan syariah (LNFINCG) tidak merinci mana bagian yang termasuk transaksi bagi hasil (mudharabah) dan mana yang jual-beli (murabahah). Sehingga, untuk selanjutnya perlu dilakukan studi lanjutan terkait hal tersebut. Begitu pula perlu dicari jalur (channel) lain dalam hal transmisi moneter syariah di Indonesia. Bukan hanya jalur pembiayaan (kredit) seperti yang telah dilakukan oleh riset ini. 


\section{DAFTAR PUSTAKA}

Amin, A. Riawan, (2007), Satanic Finance. Jakarta: Celestial Publishing.

Ascarya, (2007), Sistem Keuangan dan Moneter Islam, Pusat Pendidikan dan Studi Kebanksentralan, Bank Indonesia.

Ascarya, Hasanah, Heni dan N.A. Achsani, "Permintaan Uang dan Stabilitas Moneter dalam Sistem Keuangan Ganda di Indonesia," Paper dipresentasikan pada "Seminar dan Kolokium Nasional Sistem Keuangan Islam II", Bandung, Indonesia, 6 September 2008.

Djohanputro, Bramantyo, (2006), Prinsip-Prinsip Ekonomi Makro. Jakarta: Penerbit PPM.

Gujarati, Damodar, (2003), Ekonometrika Dasar, Terjemahan. Jakarta: Erlangga.

Hardianto, Erwin, (2004), "Mekanisme Transmisi Syariah di Indonesia." Paper.

Hasanah, Heni, 2007, "Stabilitas Moneter pada Sistem Perbankan Ganda di Indonesia, " Skripsi pada Fakultas Ekonomi dan Manajemen Institut Pertanian Bogor: tidak diterbitkan.

Hatta, M., "Telaah Singkat Pengendalian Inflasi dalam Perspektif Kebijakan Moneter Islam", Paper, Jurnal Ekonomi Ideologis, 2008.

Mankiw, N. Gregory, (2003), Teori Makroekonomi Edisi ke-5, Terjemahan. Jakarta: Penerbit Erlangga.

Nikmawati, Khulailatun, (2007), Mekanisme Transmisi Melalui Sharia Financing, Analisis Vector Autoregression (Studi Kasus Negara Malaysia). Skripsi pada Program Studi Ilmu Ekonomi Syariah STEI Tazkia Bogor: tidak diterbitkan.

Pohan, Aulia, (2008), Kerangka Kebijakan Moneter dan Implementasinya di Indonesia, Jakarta:

PT Raja Grafindo Persada.

Sakti, Ali, (2007), Sistem Ekonomi Islam: Jawaban atas Kekacauan Ekonomi Modern, Jakarta: Paradigma \& Aqsa Publishing.

Setiawan, Hapid, (2007), Analisis Faktor Dominan Penyebab Inflasi di Indonesia dan Beberapa Penyelesaiannya Menurut Ekonomi Islam, Skripsi pada Program Studi Ilmu Ekonomi Syariah STEI Tazkia Bogor: tidak diterbitkan. 